\title{
Hafif Seyirli COVID-19 Hastalarının İnfeksiyondan Altı Ay Sonraki Mortalite ve Reinfeksiyon Oranları
}

\section{Mortality and Reinfection Rates of the Patients with Mild COVID-19 at the Sixth Month after the Infection}

\author{
Arzu NAZLI'(iD), Ahmet Naci EMECEN²(iD), Özlem Oya EREN KUTLUSOYLU'(IiD), \\ Gökçen ÖMEROǴLU ȘIMȘEK ${ }^{3}$ (IID), Aylin ÖZGEN ALPAYDIN ${ }^{3}$ (iD), Bașak BAYRAM ${ }^{4}$ (IID), \\ Özgür APPAK ${ }^{5}$ (ID), Belgin ÜNAL 2(iiD), Nur YAPAR'(IID), Vildan AVKAN OG̃UZ'(ID)
}

\footnotetext{
${ }^{1}$ Dokuz Eylül Üniversitesi Tıp Fakültesi, İnfeksiyon Hastalıkları ve Klinik Mikrobiyoloji Anabilim Dalı, İzmir, Türkiye

${ }^{2}$ Dokuz Eylül Üniversitesi Tıp Fakültesi, Halk Sag̃lığı Anabilim Dalı, Epidemiyoloji Bilim Dalı, İzmir, Türkiye

3 Dokuz Eylül Üniversitesi Tıp Fakültesi, Gög̈üs Hastalıkıarı Anabilim Dalı, İzmir, Türkiye

${ }^{4}$ Dokuz Eylül Üniversitesi Tıp Fakültesi, Acil Tıp Anabilim Dalı, İzmir, Türkiye

${ }^{5}$ Dokuz Eylül Üniversitesi Tıp Fakültesi, Tıbbi Mikrobiyoloji Anabilim Dalı, Viroloji Bilim Dalı, İzmir, Türkiye
}

Makale atıfı: Nazlı A, Emecen AN, Eren Kutlusoylu ÖO, Ömeroğlu Şimşek G, Özgen Alpaydın A, Bayram B ve ark. Hafif seyirli COVID-19 hastalarının infeksiyondan altı ay sonraki mortalite ve reinfeksiyon oranları. FLORA 2021;26(2):267-76.

\section{ÖZ}

Giriş: COVID-19 pandemisinde hastalara klinik ağırlığına göre takip ve tedavi önerilmektedir. Bu çalısmada evde takip önerilen, hafif kliniği olan hastaların hastalık kötüleşmesi nedeniyle hastaneye yatışları, altı ay içinde mortalite ve reinfeksiyon oranlarının belirlenmesi amaçlanmıştır.

Materyal ve Metod: Geriye dönük olarak planlanan çalışmaya salgının ilk ayında pandemi polikliniğinde kesin COVID-19 tanısıyla (SARS CoV-2 PCR testi pozitif) evde izlemi önerilen tüm hastalar $(n=210)$ alınmıştır. Başvuru sırasındaki şikâyetleri, demografik özellikler, laboratuvar sonuçları ve verilen tedaviler kayıt edilmiştir. Tanıdan altı ay sonra hastalar telefonla aranmıştır. Hastalara, hastalığın kötüleşmesi nedeniyle ilk ayda hastaneye yatışları, altı ay içinde herhangi bir nedenden hastaneye yatışları, altı ay içindeki olası reinfeksiyon bulguları, güncel şikâyetleri sorulmuştur. Hastaların ilk aydaki ve altıncı aydaki mortaliteleri hastane kayıtlarından elde edilmiştir.

Bulgular: Çalışmaya 210 hasta alınmıştır; 103 (\%49)'ü erkektir. Hastaların yaş ortalaması $41.6 \pm 15.7$ (16-96) yıl bulunmuştur. Başvuru tarihinde 168 (\%80) hastanın şikâyetinin olduğu, 52 (\%24.8) olguda ek hastalık bulunduğu tespit edilmiştir. Kırk altı hastanın (\%26) toraks bilgisayarlı tomografi (BT) görüntülemesinde COVID-19 infeksiyonu ile uyumlu bulgular saptanmıştır. Yirmi yedi hasta, hastalığın kötüleşmesi nedeniyle (\%16.5) servise yatırımıştır. Dört (\%2.4) hastada yoğun bakım ihtiyacı gelişmiştir. Çok değişkenli analiz değerlendirilmesinde ek hastalık bulunması, hastaneye yatıs riskini 8.2 kat (\%95 GA 2.29-33.12), D-dimer değerinin $\geq 1$ ug/ mL olması 17.8 kat (\%95 GA 3.42-113.3) ve toraks BT'de yaygın tutulum olması 5.3 kat (\%95 GA 1.46-21.76) artırmıştır. Hiçbir risk faktörü olmayan, toraks BT'de tutulumu olmayan, 50 yaş altındaki 48 hastadan 2'sinde (\%4.1) hastalığın kötüleşmesi nedeniyle yatış ihtiyacı olmuştur. ilk ayda olguların tamamının sağ kaldığı gözlenmiştir. Altıncı ayda ise dört kişi (\%1.9) altta yatan hastalıklarına bağı olarak yıl kaybedilmiştir. Ilk epizottan altı ay sonra altı olgu (\%3.6) olası COVID-19 reinfeksiyonu olarak değerlendirilmiştir. Olguların 26 (\%15.6)'sı geçirdikleri COVID-19 infeksiyonuna bağlı olduğunu düşündükleri şikâyetler belirtmişlerdir.

Sonuç: Hafif klinik ile başvuran COVID-19 hastalarının, ek hastalık bulunması, D-dimer değerinin yüksek olması ve toraks BT'de yaygın tutulum olması halinde hastaneye yatırılarak izlenmesi daha iyi bir tercih olabilir.

Anahtar Kelimeler: COVID-19 infeksiyonu; Mortalite; Reinfeksiyon; Klinik ağırlık; Post-COVID-19 sendromu

Geliș Tarihi/Received: 04/03/2021 - Kabul Ediliș Tarihi/Accepted: 19/04/2021

${ }^{\circledR}$ Telif Haklı 2021 Flora. Makale metnine www.floradergisi.org web adresinden ulașılabilir. 


\title{
ABSTRACT \\ Mortality and Reinfection Rates of the Patients with Mild COVID-19 at the Sixth Month after the Infection
}

\author{
Arzu NAZLI', Ahmet Naci EMECEN², Özlem Oya EREN KUTLUSOYLU', Gökçen ÖMEROG̃LU ȘIMȘEK ${ }^{3}$,

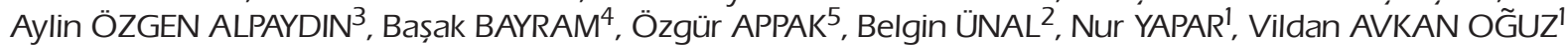

\footnotetext{
${ }^{1}$ Department of Infectious Diseases and Clinical Microbiology, Dokuz Eylül University Faculty of Medicine, İzmir, Turkey

${ }^{2}$ Department of Public Health, Division of Epidemiology, Dokuz Eylül University Faculty of Medicine, İzmir, Turkey

3 Department of Chest Diseases, Dokuz Eylül University Faculty of Medicine, İzmir, Turkey

${ }^{4}$ Department of Emergency Medicine, Dokuz Eylül University Faculty of Medicine, İzmir, Turkey

${ }^{5}$ Department of Medical Microbiology, Division of Virology, Dokuz Eylül University Faculty of Medicine, İzmir, Turkey
}

Introduction: The management of the patients with COVID-19 is depend on the clinical presentation. We aimed to evaluate the hospitalization rates due to the progression of the illness in the fist month, the mortality and reinfection rates of the patients with mild COVID-19 during the six months follow-up.

Materials and Methods: The study with retrospective design included all SARS CoV-2 PCR positive patients presenting with mild disease to our hospital and who were recommended at-home follow-up during the first month of the COVID-19 pandemic. Demographic characteristics, baseline symptoms, laboratory results and the treatments administered were recorded. The patients were called by phone at six months after the diagnosis. Patients were asked to report hospitalisation at first month, hospitalisation due to any reason and possible reinfections and current symptoms at six month. We noted the mortality rates at first month and at six months from hospital records.

Results: The study included 210 patients; 130 patients were male. The mean age was $42.3 \pm 15.7$ (16-96) years. At baseline, 168 patients (80\%) were symptomatic. Fifty-two patients (75.2\%) had comorbidities. Thorax computed tomography (CT) was congruent with COVID-19 infection in 46 patients (26\%). Twenty-seven patients (16.5\%) were hospitalised due to the progression of clinical condition and four (2.4\%) needed intensive care transmission. In multivariate analysis, those with comorbidity had having 8.2 fold (95\% Cl 2.2933.12) D-dimer $\geq 1 \mathrm{ug} / \mathrm{mL}$ had 17.8 fold (OR: 17.8, \%95 GA: 3.42-113.3), and diffuse infiltrations in thorax CT scan had 5.36-fold (95\% Cl 1.46-21.76) higher relative risk for post-COVID hospitalisation. Two (4.1\%) out of 48 patients younger than 50 years old and with no risk factors and a normal thorax CT needed hospitalisation. There was no mortality at first month. Four patients (1.9\%) died due to deterioration of underlying condition during the six-month follow up. Six patients (3.6\%) were considered to be reinfected six months after the first episode. Twenty-six patients (15.6\%) had current symptoms which they belived had occured after COVID-19 infection.

Conclusion: In the case of the presence of comorbidities, high D-dimer value and diffuse infiltration in thorax CT scan in mild COVID-19 patients, hospitalisation may be the optimal approach.

Key Words: COVID-19 infection; Mortality; Reinfection; Clinical severity; Post-COVID-19 syndrome

\section{GíRiș}

COVID-19 pandemisinde, hastalığın kliniği asemptomatik, hafif-orta seyirli ve ciddi solunum yetmezliği seklinde görülebilmektedir ${ }^{[1,2]}$. Cin Hastallk Önleme Merkezi'nin (Chinese Center of Disease Control and Prevention) genis çaplı hasta verilerine göre hastaların \%81'i hafif, \%14'ü ağır ve $\% 5$ 'i de kritik klinik ile seyretmiștir ${ }^{[3]}$. Ölümlerin hepsi kritik kliniği olan olgularda görülmüs, hafif ve ağır olgularda ölüm olmamıștır[3]. Epidemiyolojik verilerin sonuçları ve sağlı sistemindeki kapasite göz önüne alınarak Çin'de, klinik ağırlığa göre hasta yönetimi yaklașımı benimsenmiștir ${ }^{[4]}$.
Türkiye'de salgının ilk dalgası Mart 2020'de bașlamıștır. Sağlık Bakanlığının 13.04.2020 tarihli 'Erișkin Hasta Yönetimi Tedavi Rehberi'nde hastalığın klinik ağırlığına göre tedavi izlemi önerilmektedir ${ }^{[5]}$. Buna göre, asemptomatik ya da hafif-orta hastalık tablosu (hipoksi bulguları olmayan) ile bassvuran hastaların genel durumunu ve ateșini izlemesi ve bulgularında kötüleșme olması durumunda tekrar hastaneye gelmesi belirtilerek 'Evde İzolasyon' ile izlemi önerilmiștir. Calıșmamızda, salgının ilk dalgasının ilk ayında yapılan bu önerilerin, gerçek hayattaki yansımasını görebilmek için, evde izlem kararı verilen hastaların hastalık 
progresyonu nedeniyle ilk bir ay içinde hastaneye yatıs oranlarının, 1 ve 6 . aydaki mortalitelerinin, altınc1 aydaki sikayetlerinin ve reinfeksiyon oranlarının değerlendirilmesi amaçlanmıștır.

\section{MATERYAL ve METOD}

Calıșma için Dokuz Eylül Üniversitesi Tıp Fakültesi Girișimsel Olmayan Bilimsel Calıșmalar Etik Kurulundan (Tarih: 20.05.2020, Karar no: 2020/10-36) onay alınmıstır.

\section{Çalıșma Grubu}

Calıșmanın yapıldığı hastanenin pandemi polikliniğine 17.03.2020 ile 17.04.2020 tarihleri arasında bașuran hastalardan, SARS CoV-2 polimeraz zincir reaksiyonu (PZR) testi pozitif olan ve evde izlemine karar verilen 18 yas ve üzerinde 210 olgu calıșmaya alınmıștır.

Hastaların demografik verileri, altta yatan hastalıkları, bașvuru sikвyetleri, laboratuvar değerleri, radyolojik değerlendirmeler (infeksiyon hastalıkları ve göğuis hastalıkları uzmanları 'British Society of Thorax Imagining' sinıflamasına göre değerlendirilmeleri ${ }^{[6]}$, epikriz notları, takibinde önerilen tedaviler hastane kayıt sisteminden geriye dönük olarak elde edilmiștir. Hastalar altıncı ayda telefonla aranarak ilk bașvurularından sonraki bir ay içinde hastalığın kötüleșmesi nedeniyle hastanede yatıp yatmadıkları, yoğun bakım ihtiyaçları olup olmadığı, altı ay içinde tekrar COVID-19 gecirip geçirmedikleri, altı ay içinde herhangi bir nedenden hastane yatıșları ve altıncı aydaki șikByetleri sorgulanmıștır. Hastaların birinci ve altıncı aydaki mortaliteleri hastane kayit sisteminden belirlenmiștir.

\section{Reinfeksiyon Tanımı}

COVID-19 reinfeksiyonlarını değerlendirmek için Centers for Disease Control and Prevention (CDC) tarafından yapılan süpheli vaka tanımı esas alınmıș, COVID-19 hastalığına benzer șikByeti olsun olmasın, ilk hastalıtan $\geq 90$ gün sonra tekrar SARS-CoV-2 PZR testi pozitif olanlar ve 45-89 gün sonra COVID-19 infeksiyonuna benzer semptomu olanlar olası reinfeksiyon olarak kabul edilmiștir $^{[7]}$.

\section{Klinik Ağırlığa Göre Hasta Yönetimi}

Sağlık Bakanlığının Nisan 2019 tarihli rehberine göre hastalar, komplike olmayan ve pnömonili hasta (hafif-orta ve aŏır pnömoni) seklinde sınıflandırılmıștır. Lenfosit sayısının $\leq 800 / \mathrm{mm}^{3}$, C-reaktif protein (CRP) değerinin $\geq 40 \mathrm{mg} / \mathrm{L}$ olması, ferritin değerinin $\geq 500 \mathrm{ng} / \mathrm{mL}$ ve $\mathrm{D}$-dimer değerinin $\geq 1 \mathrm{ug} / \mathrm{mL}$ olması kötü prognoz göstergesi olarak kabul edilmiștir ${ }^{[5]}$.

\section{İstatistiksel Analiz}

Kategorik değișkenler sayı ve yüzde (\%), sürekli değișkenler ortanca ve en küçük-en büyük değerler olarak sunulmuștur. Kategorik değiskenler ki-kare testi ya da Fisher'in kesin testi ile karșlastırılmıstır. Bir aylık süre sonunda hastane yatıșı varlığını öngörmek için cinsiyet, sağlık çalıșanı olma, sikayet varlığı, ek hastalık varlığı, tedavi alma durumu ve kötü prognoz göstergeleri değişkenlerini içeren tek değișkenli lojistik regresyon modelleri olușturulmuștur. Tek değișkenli analizde istatistiksel olarak anlamlı çkan değișkenler için cok değișkenli lojistik regresyon modeli olușturulmuștur. Risk ölçütü (odds oranı-OR) \%95 güven aralığı (\%95 GA) ile sunuldu. İstatistiksel analizler $\mathrm{R}$ versiyon 3.6.1 (a language and environment for statistical computing, $\mathrm{R}$ Foundation for Statistical Computing, Vienna, Austria. URL: https:// www.R-project.org) ile yapılmıstır. İki yönlü $\mathrm{p}$ değerinin $\leq 0.05$ olduğu durumlar istatistiksel olarak anlamlı kabul edilmiștir.

\section{BULGULAR}

Salgının ilk ayında pandemi polikliniğine bașvuran ve COVID-19 ön tanısıyla U07.3 tanı kodu kodlanan 2094 hasta geriye dönük taranmıștır. Calıșmaya dahil olma ölçütlerini karșılayan 210 hasta (18 yas üzeri, SARS-CoV 2 PZR ile kesin COVID-19 tanisı konan ve evde izlem kararı verilen) calıșmaya alınmıștır.

\section{Demografik Veriler}

Hastaların yas ortalaması $41.6 \pm 15.7$ yll (1696)'dir. Bașvuru tarihinde 42 (\%20) hastanın sikayetinin olmadığı, 148 (\%75.2) olguda ek hastalık bulunmadığı tespit edilmiștir (Tablo 1). Hastalarda ağır infeksiyonu düșündürecek tașikardi (>100/dk), takipne (solunum sayisı $>30 / \mathrm{dk}$ ) ve/veya hipoksi (oda havasında satürasyon <\%93) bulgusu saptanmamıștır.

\section{Laboratuvar Bulguları}

Hastaların 27 (\%12.8)'sinde kan tetkiki yapılmamıștır. Tetkik istenen hastaların laboratuvar 


\begin{tabular}{|c|c|}
\hline & $n=210(\%)$ \\
\hline Yaş ( $\geq 50 \mathrm{yıl})$ & $53(25.2)$ \\
\hline Erkek cinsiyet & $103(49)$ \\
\hline Sağlık çalışanı & $71(33.8)$ \\
\hline Eşlik eden hastalık varlığı & $52(24.8)$ \\
\hline Hipertansiyon & $29(13.8)$ \\
\hline Diyabet & $16(7.6)$ \\
\hline Kronik akciğer hastalığı & $12(5.7)$ \\
\hline Koroner arter hastalığı & $8(3.8)$ \\
\hline Kanser & $8(3.8)$ \\
\hline Nörolojik hastalık & $3(1.4)$ \\
\hline Şikâyet varlığı & $168(80)$ \\
\hline Öksürük & $85(40.5)$ \\
\hline Halsizlik & $74(35.2)$ \\
\hline Ateş & $60(28.6)$ \\
\hline Baş ağrısı & $53(25.2)$ \\
\hline Miyalji & $50(23.8)$ \\
\hline Boğaz ağrısı & $50(23.8)$ \\
\hline Nefes darlığı & $30(14.3)$ \\
\hline İshal & $26(12.4)$ \\
\hline Bulantı-kusma & $12(5.7)$ \\
\hline Tat alamama & $11(5.2)$ \\
\hline Koku alamama & $9(4.3)$ \\
\hline
\end{tabular}

verilerinin ortanca değerleri Tablo 2'de verilmiștir. Bu hastaların \%92.8 (169/183)'inde lenfosit $\leq 800$ hücre $/ \mathrm{mm}^{3}, \% 3.4$ (6/173)'ünde CRP $\geq 40 \mathrm{mg} / \mathrm{dL}$, \%2.3 (3/128)'ünde ferritin $\geq 500 \mathrm{mg} / \mathrm{dL}$ ve $\% 10.4$ (17/163)'ünde D-dimer $\geq 1 \mathrm{ug} / \mathrm{mL}$ saptanmıștır.

\section{Radyolojik Görüintiileme}

Hastaların toraks bilgisayarlı tomografi (BT) görüntülemesinin rutinde raporlanan sonuçarı Tablo 2'de verilmiștir. Radyolojik görüntülemesi COVID-19 pnömonisi ile uyumlu olan 46 hastaların 9'unda (\%19.6) hafif tutulum, 37'sinde (\%80.4) orta-ağır tutulum rapor edilmiștir.

\section{Tedaviler}

Yüz altmıs hastaya (\%76.2) hidroksiklorokin tedavisi bașlanmıștır. Elli hastaya ise (\%23.8) tedavi verilmemiștir. Buna ek olarak 13 (\%6.2) olgu osel- tamavir, dört (\%1.9) olgu azitromisin, dört (\%1.9) olgu levofloksasin ve dört (\%1.9) olgu düșuik molekül ağırlıklı heparin (DMAH) kullanmıștır.

\section{Takip Sonuçları}

Takipte 27 (\%12.8) hasta bir ay içinde hastal1ğın kötüleșmesi nedeniyle pandemi servislerine yat1rılmıștır. Servis yatıșı olan hastaların 12 (\%44.4)'si hastanemizde, 10 (\%37)'u ilimizdeki bașka hastanelerde ve 5 (\%18.5)'i hem hastanemizde hem de taburculuğun ardından dıș merkezde yatarak izlenmiștir. Bu hastalardan 4 (\%16)'ünün yoğun bakım ihtiyacı olmuștur. Yoğun bakım ihtiyacı olan hastaların hepsi dıș merkez yoğun bakımda izlenmiștir.

Olguların hiçbirinde birinci ayda mortalite görülmemiștir. Takip sonuçarı Tablo 3'te verilmiștir. Altıncı ayda dört kișide (\%1.9) mortalite görülmüștür. Ölen hastaların hepsinin yașları 50'nin üzerindedir ve tümünde, zemindeki hastalığın (malignite) ilerlemesi nedeniyle ölüm olduğu düșünülmektedir.

Bir aylık süre içinde hastaneye yatıs varlığını gösteren risk faktörleri Tablo 4'te gösterilmiștir. Tek değișkenli analizlerde 50 yas ve üzerinde olmak (OR: 6.82, \%95 GA: 2.91-16.80), sağlık çalıșanı olmamak (OR:4.51, \%95 GA: 1.49-20.30), ek hastalık varlığı (OR: 10.5, \%95 GA: 4.35-27.80), D-dimer düzeyinin $\geq 1 \mathrm{ug} / \mathrm{mL}$ olması (OR: 19.5, \%95 GA: 6.26-67.40) ve toraks BT'de orta-ağır tutulum olması (OR: $2.67 \% 95$ GA: 1.02-6.72) bağımsız risk faktörü olarak bulunmuștur. Çok değișkenli analizde ek hastalık varlığı (OR: 8.25, \%95 GA: 2.29-33.12), D-dimer düzeyinin $\geq 1$ ug/ mL olması (OR: 17.8, \%95 GA: 3.42-113.3) ve toraks BT'de orta-ağır tutulum olması (OR: 5.36 \%95 GA: 1.46-21.76) yatı̣ riskini arttıran faktörler olarak bulunmuștur.

Altıncı ayda 26/163 (\%15.9) hastalar sikayet belirtmișlerdir. Bunlar koku ve/veya tat değișikliği (9/26), nefes darlığı (5/26), çarpıntı (3/26), göğuiste baskı hissi (3/26), baș ağrısı (2/26), öksürük (1/26), halsizlik (1/26), astigmat derecesinde ilerleme $(1 / 26)$ ve uykusuzluk $(1 / 26)$ olarak belirlenmiștir.

Hastaların \%3.6 (6/163)'sında COVID-19 reinfeksiyonu ile uyumlu sikayetler gelișmiștir. Olası reinfeksiyon olarak kabul edilen hastaların özellikleri Tablo 5'te verilmiștir. 


\section{Tablo 2. Hastaların başvuru sırasındaki tetkik sonuçları}

\begin{tabular}{lcc} 
& $\mathbf{n}$ & Ortanca (min-maks) \\
\hline Lökosit $\left(/ \mathrm{mm}^{3}\right)$ & 183 & $5900(2300-22400)$ \\
Lenfosit $\left(/ \mathrm{mm}^{3}\right)$ & 182 & $1700(400-4600)$ \\
Trombosit $\left(/ \mathrm{mm}^{3}\right)$ & 183 & $240000(31000-471000)$ \\
Kreatinin $(\mathrm{mg} / \mathrm{dL})$ & 183 & $0.70(0.40-4.80)$ \\
Alanin aminotransferaz (U/L) & 179 & $23(7-137)$ \\
Laktat dehidrogenaz (U/L) & 135 & $174(102-480)$ \\
Ferritin $(\mathrm{ng} / \mathrm{mL})$ & 128 & $59.5(3.6-15000)$ \\
C-reaktif protein $(\mathrm{mg} / \mathrm{L})$ & 173 & $3.6(0.20-166.6)$ \\
Prokalsitonin $(\mathrm{ng} / \mathrm{L})$ & 160 & $0.03(0.01-21)$ \\
D-dimer (ug/mL) & 163 & $0.3(0.10-27.6)$ \\
Toraks BT görüntüleme & 177 & $\mathbf{n}(\%)$ \\
$\quad$ Tutulum yok & $102(\% 57.6)$ & \\
COVID-19 infeksiyonu ile uyumlu hafif tutulum & $9(\% 5.1)$ & \\
COVID-19 infeksiyonu ile uyumlu orta-ağır tutulum & $37(\% 20.9)$ & \\
COVID-19 infeksiyonu açısından belirsiz bulgular & $20(\% 11.3)$ & \\
COVID-19 infeksiyonu ile uyumsuz bulgular & $9(\% 5.1)$ & \\
\hline
\end{tabular}

*BT: Bilgisayarlı tomografi.

Tablo 3. Ayaktan takip edilen hastaların ilk ay ve 6 aylık takip sonuçları

\begin{tabular}{lcc} 
Sonuç & $\mathbf{N}$ & $\mathbf{n}(\%)$ \\
\hline Bir ay içinde COVID-19 nedeniyle hastane yatışı & 210 & $27(12.8)$ \\
Bir ay içinde mortalite & 210 & $0(0)$ \\
Altıncı ayda şikâyet varlığı & 163 & $26(15.9)$ \\
Altı ay içinde herhangi bir nedenden yatış* & 163 & $6(3.6)$ \\
Altı ay içinde mortalite & 210 & $4(1.9)$ \\
Altı ay içinde reinfeksiyon & 163 & $6(3.6)$ \\
\hline
\end{tabular}

*ilkk aydaki yatışlar dâhil edilmemiştir. Yatış nedenleri; Miyokart enfarktüsü nedeniyle angio (1), planlamış endoskopi (1) ve doğumdur (4).

\section{TARTIȘMA}

Devam eden COVID-19 pandemisinde TC Sağlık Bakanlığı, Dünya Sağlık Örgütü (DSÖ) ve CDC rehberlerinde hastalığın klinik ağırlığına göre hastaneye yatıs veya evde izlem önerileri devam etmektedir ${ }^{[5-8]}$. Birçok hekim günlük pratikte, klinik bulguları hafif olarak değerlendirilen hastalara evde izlem önerildikten sonra, hastaların bazılarının ağır klinikle tekrar hastaneye geldiklerini, yoğun bakım ihtiyacı olduğunu ve bazen de kaybedildiklerini deneyimlemiștir. Bu calıșmada, salgının ilk ayında pandemi polikliniğinden evde takip önerilen hastaların \%12.8'ine ilk ay icinde hastalığın kötüleșmesi nedeniyle yatıș yapıldığı ve yatıs yapılanların \%14.8'inin yoğun bakım ihtiyac1 olduğu, buna karșllı olguların tamamının sağ kaldığ gözlenmiștir. Hafif ve orta kliniği olan hastaların değerlendirildiği farklı çalıșmalarda da hastaların \%9.9-\%10.9'unun, hastalığın kötüleșmesi nedeniyle bir üste merkeze sevk edildiği bildirilmis ve iki haftalı takipte bu hasta gruplarında da ölüm görülmemiștir ${ }^{[9,10]}$. Bu çalıșmada hastaların hastaneye yatıs oranının daha yüksek bulunması, önceki calıșmalarda hastaların izlem süresinin daha kısa olmasına bağlı olabilir. 
Tablo 4. Klinik ve laboratuvar özelliklerine göre birinci ay sonunda hastane yatış, tek değişkenli ve çok değişkenli analiz sonuçları

\begin{tabular}{|c|c|c|c|c|c|}
\hline & $\mathbf{n}$ & Yatış var $n=27$ & ${ }^{*} p$ & ýOR (\%95 GA) & §OR (\%95 GA) \\
\hline Cinsiyet, n (\%) & 210 & & $>0.99$ & & \\
\hline Kadın & & $14(13.1)$ & 1 & & - \\
\hline Erkek & & $13(12.6)$ & & $0.96(0.42-2.18)$ & - \\
\hline Yaş, n (\%) & 210 & & $<0.01$ & & \\
\hline$<50$ yıl & & $10(6.4)$ & & 1 & 1 \\
\hline$\geq 50 \mathrm{yll}$ & & $17(32.1)$ & & $6.82(2.91-16.80)$ & $1.55(0.38-5.93)$ \\
\hline Sağlık çalışanı, n (\%) & 210 & & 0.01 & & \\
\hline Hayır & & $24(17.3)$ & & $4.51(1.49-20.30)$ & $0.84(0.16-3.60)$ \\
\hline Evet & & $3(4.2)$ & & 1 & 1 \\
\hline Şikayet, n (\%) & 210 & & 0.96 & & \\
\hline Yok & & $6(14.3)$ & & 1 & - \\
\hline Var & & $21(12.5)$ & & $0.84(0.33-2.48)$ & - \\
\hline Ek hastalık, n (\%) & 210 & & $<0.01$ & & \\
\hline Yok & & $8(5.1)$ & & 1 & 1 \\
\hline Var & & $19(36.5)$ & & $10.5(4.35-27.80)$ & $8.25(2.29-33.12)$ \\
\hline Tedavi, n (\%) & 210 & & 0.16 & & \\
\hline İlaçsız izlem & & $3(6.0)$ & & 1 & - \\
\hline Klorokin & & $24(15.0)$ & & $2.64(0.86-12.0)$ & - \\
\hline Lenfosit, n (\%) & 182 & & 0.39 & & \\
\hline$\leq 800 / \mathrm{mm}^{3}$ & & $21(12.4)$ & & 1 & - \\
\hline$>800 / \mathrm{mm}^{3}$ & & $3(23.1)$ & & $2.17(0.44-7.95)$ & - \\
\hline Ferritin, $\mathbf{n}(\%)$ & 128 & & $<0.01$ & & \\
\hline$<500 \mathrm{ng} / \mathrm{mL}$ & & $14(11.2)$ & & 1 & - \\
\hline$\geq 500 \mathrm{ng} / \mathrm{mL}$ & & $3(100)$ & & $\hat{Y}$ & - \\
\hline CRP, n (\%) & 173 & & 0.14 & & \\
\hline$<40 \mathrm{mg} / \mathrm{L}$ & & $18(10.8)$ & & 1 & - \\
\hline$\geq 40 \mathrm{mg} / \mathrm{L}$ & & $2(33.3)$ & & $4.22(0.49-24.7)$ & - \\
\hline D-dimer, n (\%) & 163 & & $<0.01$ & & \\
\hline$<1 \mathrm{ug} / \mathrm{mL}$ & & $12(8.2)$ & & 1 & 1 \\
\hline$\geq 1 \mathrm{ug} / \mathrm{mL}$ & & $11(64.7)$ & & $19.5(6.26-67.40)$ & $17.8(3.42-113.3)$ \\
\hline Toraks BT'de orta-ağır tutulum, n (\%) & 177 & & 0.06 & & \\
\hline Yok & & $15(10.7)$ & & 1 & 1 \\
\hline Var & & $9(24.3)$ & & $2.67(1.02-6.72)$ & $5.36(1.46-21.76)$ \\
\hline ||Kötü prognostik faktör, n (\%) & 109 & & $<0.01$ & & \\
\hline Yok & & $4(5.6)$ & & 1 & \\
\hline Var & & $11(29.7)$ & & $6.89(2.11-27.6)$ & - \\
\hline
\end{tabular}

*ki-kare testi, Ý: hesaplanamadı, ý: Tek değişkenli analiz sonucu OR, §: Çok değişkenli analiz sonucu OR. || Kötü prognostik faktörlerden ( $\geq 50$ yaş, $\leq 800$ lenfosit sayısı, $\geq 40 \mathrm{CRP}, \geq 500$ ferritin, $\geq 1 \mathrm{D}$-dimer) en az birisinin varlığı olarak tanımlanmıştır. Laboratuvar değerlendirmesi olan hastalar üzerinden hesaplanmıştır. 


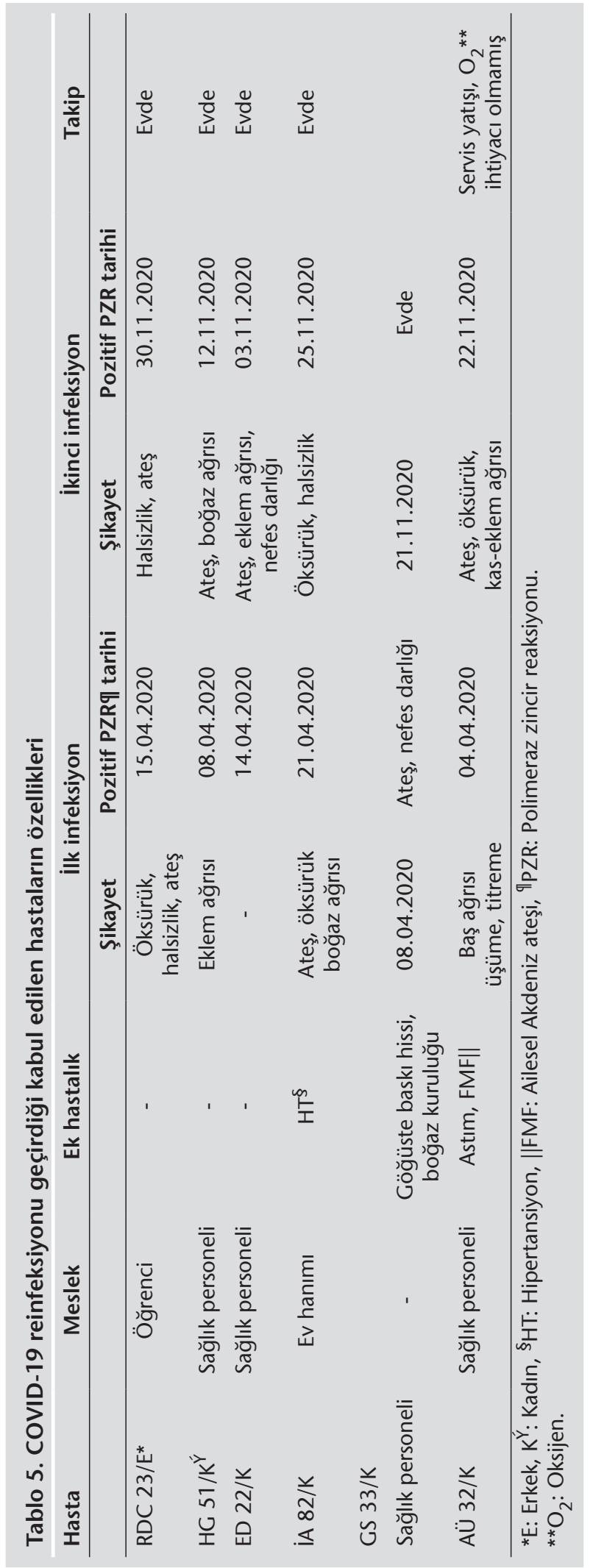

Sağlık Bakanlığı rehberine göre laboratuvar bulgularında lenfosit sayısının $\leq 500$ hücre $/ \mathrm{mm}^{3}$, CRP değerinin $\geq 40 \mathrm{mg} / \mathrm{dL}$, ferritin değerinin $\geq 500 \mathrm{mg} / \mathrm{dL}$ ve D-dimer değerinin $\geq 1 \mathrm{ug} / \mathrm{mL}$ olması kötü prognostik faktörler olarak belirtilmiştir $^{[5]}$. Calıșmamızda tek değișkenli analizde $>50$ yașında olmak, ek hastalığı bulunmak, D-dimer değerinin $>1$ olması, toraks BT'de orta-ağır tutulum olması ve laboratuvar değerine göre kötü prognostik faktörlerden en az birinin olması hastaneye yatıș için risk fatörü olarak saptanmıs olmakla birlikte, cok değișkenli analizde sadece ek hastalık bulunması, D-dimer değerinin $\geq 1 \mathrm{ug} / \mathrm{mL}$ olması ve toraks BT de tutulum olması istatistiksel anlamlllığını sürdürmüștür. Türkiye'den ve diğer bazı ülkelerden yapılan yayınlarda hafif-orta seyirli hastalardan hastalığı kötüleșenlerde benzer risk faktörleri saptanmıștır ${ }^{[3,11-13]}$. Buna karșlltk bașvuru sırasında komplike olmayan hastalı tablosuyla gelen, ek hastalığı ve risk faktörü olmayan genç hastalarda da hastaneye yatıs oranı (\%4.1) dikkate değer bulunmustur.

Diğer bir tartışmaya açık konu da tedavinin prognoz üzerine etkisidir. Tedavinin hastaneye yatıs ile anlamlı bir ilișkisi tespit edilmemiștir. COVID-19 infeksiyonunun kabul edilmis bir tedavisi bulunmamaktadır ${ }^{[7,8]}$. FDA tarafından tedavide onaylanan tek antiviral remdesivir olup diğer antiviraller, antikoagulanlar ve antiinflamatuvarlar tedaviler ile ilgili calıșmalar devam etmektedir. Bu çalıșmanın yapıldığı dönemde ayakta takip edilen hastalara hidroksiklorokin tedavisi önerilmekteydi. Calıșmada hastaların \%76.2'si hidroksiklorokin tedavisi almıstır. Ancak daha sonra yayınlanan pek çok randomize kontrollü çalıșmada hidroksiklorokinin hafif-orta ve ağır seyirli hastalarda iyilesmeye etkisi olmadığı gösterilmiștir ${ }^{[14-16]}$.

Reinfeksiyon konusunda da halen tartıșmalar devam etmektedir. İlk pozitif SARS-CoV-2 PZR testinden sonra iki negatif PZR testi görülmesi ve bir süre sonra PZR testinin tekrar pozitiflesmesinin nedeni, uzamıs viral salınım, PZR testinin örnek alımında veya bașka bir teknik hata sebebi ile yanlıs negatif olması veya yeni bir tür SARS-CoV-2 virüsü ile reinfeksiyon geçirmek olabilir ${ }^{[7,8,17]}$. Literatürde bildirilen en uzun viral salınım süresi 118 gündür ${ }^{[17]}$. Bu çalıșmada ise COVID-19 reinfeksiyonlarını değerlendirmek için 
CDC'nin kullandığı șüpheli vaka tanımına uyan 6 (\%3.6) hastada iki negatif PZR testi görüldükten altı ay sonra tekrar COVID-19 infeksiyonu ile uyumlu sikayetler gelișmiș ve COVID-19 PZR testi pozitif saptanmıștır. Reinfeksiyon tanısının en doğru sekilde konulması için süpheli hastalardan her iki infeksiyon epizodundaki örneklerde tüm viral genomun sekanslanması ile farkların ortaya konması ve ek olarak her iki infeksiyonda da yüksek viral titrenin bulunması, sgmRNA'nın pozitif olması veya virolojik kültür gibi gerçek infeksiyonu gösteren bulguların olması önerilmektedir ${ }^{[18]}$. Literatürde cok sayida vaka sunumu bulunmakla birlikte, genotip tayini ile kesin tanı konan sadece dört olgu sunumu sunulmuștur ${ }^{[19-21]}$. Yeni mutant SARS-CoV-2 virüsüyle reinfeksiyon olguları Brezilya ${ }^{[22-26]}$, Birleșik Krallık ${ }^{[27]}$ ve Güney Afrika'dan [28] bildirilmiștir. Bu çalıșmada reinfeksiyon olarak değerlendirilen hastalarda her iki epizot arasında 180 günden fazla zaman bulunmaktadır. Ancak her iki epizotta virüsün tüm genom sekanslaması yapilarak farklılıklar ortaya konamadiğından reinfeksiyon teyit edilememiștir.

Post-COVID-19 sendromu tanımı net olmamakla birlikte, infeksiyonu gecirenlerde ortaya çkan bilișsel, psikososyal ve fiziksel bozukluklar olarak belirtilmektedir ${ }^{[29]}$. Akciğerler infeksiyonda ana hedef olmakla birlikte, virüsün kalp, kan damarları, böbrekler, sindirim sistemi ve beyin gibi birçok farklı organa yayıldığı gösterilmiștir ${ }^{[30]}$. COVID-19 infeksiyonunu geçiren kișilerde infeksiyonun kısa dönem etkileriyle ilgili literatürde oldukça fazla veri bulunmakla birlikte, uzun dönem etkileri hakkında yeterli ver bulunmamaktadır ${ }^{[31]}$. Bizim merkezimiz dahil ülkemizde ve birçok ülkede multidisipliner post-COVID-19 izlem klinikleri kurulmustur ${ }^{[32]}$. Wuhan'da hastane yatıșındaki hastalık ağırlığına göre 7 üzerinden $3,4,5$ ve 6 ağırlık derecesinde olan ve taburcu edildikten sonra 6 ay izlenen 1733 hastanın sonuçları yayınlanmıștır ${ }^{[33]}$. Calıșmada hastalara semptomları ve sağlık ilișkili yașam kalitesi ile ilgili anketler, fizik muayene, 6-dakikalık yürüme testi, kan testleri, pulmoner fonksiyon testi yapılmış ve yüksek çözünürlüklü toraks BT ve toraks USG çekilmiștir.

Sonucta sikayetin yorgunluk (\%6), uyku sorunları (\%26) ve depresyon (\%23) olduğu, hastalığ1 ağır gecirenlerde pulmoner difüzyon kapasitesinin daha düșük olduğu görülmüștürr ${ }^{[33]}$. Ayakta izlenen hastaların coğunlukta olduğu bașka bir çalıșmada, üçüncü ayda hastaların \%99.3'ü en sık yorgunluk ve solunum sikıntısı olmak üzere en az bir semptom bildirmiștir ${ }^{[34]}$. Altınc1 ayda telefonla ulaștığımız hastaların dikkate değer bir bölümünde (\%15.9) ceșitli yakınmalar bulunduğu ve en sık sikayelerin koku/tat bozuklukları, nefes darlığ1, çarpıntı ve göğüste baskı hissi olduğu belirtilmiștir. Koku ve tat bozukluğu COVID-19 infeksiyonunun akut dönemi için oldukça spesifik bir bulgu olup, literatürde bir aydan fazla süre devam edebildiği, yaklașı \%10 kadarının ise iyileșmesinin daha uzun sürebildiği belirtilmiștir ${ }^{[34,35]}$. Șikayeti olan hastaların ilgili polikliniklere bu sebeple bașvurmadığı anlașılmıștır. Bu durumun, birçok hastanenin pandemi hastanesi olarak hizmet vermesi, poliklinik hizmeti verememesi ve hastaların tekrar infeksiyon geçirmekten korktukları için hastanelere bașvurmaktan cekinmesi nedeniyle olabileceği düșünülmüștür. COVID-19 infeksiyonu gecirdikten sonra uzamıs sikayeti olan hastaların takip algoritmaları üzerinde calıșmalar bulunmaktadır ${ }^{[36]}$. Ancak Türkiye'de bu konuda kabul edilmis bir uzlașma raporu yoktur.

Calıșmada, altı ay içinde herhangi bir nedenle hastaneye yatıs oranı (\%3.6) düșük bulunmuștur. Bu yatıșlar gebelik, elektif endoskopi gibi COVID-19 infeksiyonu ile ilișkisiz nedenlerle olmuștur. Sadece bir hasta COVID-19 tanısı aldıktan beș ay sonra acil servise miyokart infarktüsü nedeniyle bașvurmuștur. İlk bakıșta COVID-19 infeksiyonun etkisi olabileceği düșünülse de, hastanın kendine ait risk faktörleri bulunduğundan (>50 yas, erkek cinsiyet, hipertansiyon, diyabet, sigara kullanımı) bu etkiyi değerlendirmek mümkün değildir. COVID-19 infeksiyonun erken ve gec dönemde tromboembolitik olaylar, miyokardit ve vasküler inflamasyon yoluyla kardiovasküler etkileri olduğu düșünülmektedir ${ }^{[37]}$.

Sunulan çalısmanın bașlica kısıtlılıkları; geriye dönük olması, tek merkez olması, altıncı aydaki sikayetlerin, hastaneye yatıș ve poliklinik basvurularının hastaların beyanına göre olması ve olası reinfeksiyonların, tüm genom sekanslama ile teyit edilmemiș olmasıdır.

Sonuc olarak pandeminin ilk ayında evde takip önerilen hafif COVID-19 olgularının \%12.8'inde 
hastalık kötüleșmesi nedeniyle hastaneye yatıs görülmüs ancak hastalığa bağlı mortalite görülmemiștir. Illk epizottan altı ay sonra olguların \%3.6's1 olası COVID-19 reinfeksiyonu olarak değerlendirilmiștir. Olguların \%15.6'sı altıncı ayda cesitli sikayetler beyan etmislerdir. Ayaktan takip önerilen hastalarda ek hastalık bulunması, D-dimer değerinin yüksek olması ve toraks BT'de yaygın tutulum olması izleyen dönemde hastaneye yatıs açısından risk faktörü olarak görülmüștür.

\section{ETIK KURUL ONAYI}

Calıșma için Dokuz Eylül Üniversitesi Tıp Fakültesi Girișimsel Olmayan Bilimsel Çalısmalar Etik Kurulundan (Tarih: 20.05.2020, Karar no: 2020/10-36) onay alınmıstır.

\section{ÇIKAR ÇATIȘMASI}

Yazarlar bu makale ile ilgili herhangi bir çkar catıșması bildirmemișlerdir.

\section{YAZAR KATKISI}

Anafikir/Planlama: AN, NY, BÜ, VAO

Analiz/Yorum: AN, ANF, ÖA, GÖȘ

Veri sağlama: AN, ANE, ÖA, OÖEK, GÖȘ, AÖA, BB

Yazım: AN, ANE, ÖA

Gözden Geçirme ve Düzeltme: NY, BÜ, VAO, AÖA

Onaylama: NY, BÜ, VAO, AÖA, BB, ÖA, OÖEK, GÖȘ, ANE, BÜ

\section{KAYNAKLAR}

1. Guan WJ, Ni ZY, Hu Y, Liang WH, Ou CQ, He JX, et al. Clinical characteristics of Coronavirus Disease 2019 in China. N Engl J Med 2020;382(18):1 708-20.

2. Fu L, Wang B, Yuan T, Chen X, Ao Y, Fitzpatrick $T$, et al. Clinical characteristics of coronavirus disease 2019 (COVID-19) in China: A systematic review and meta-analysis. J Infect 2020;80(6):656-65.

3. Wu Z, McGoogan JM. Characteristics of and important lessons from the Coronavirus Disease 2019 (COVID-19) Outbreak in China: Summary of a Report of 72314 Cases From the Chinese Center for Disease Control and Prevention. JAMA 2020;323(13):1239-42.

4. Gandhi RT, Lynch JB, Del Rio C. Mild or moderate COVID-19. N Engl J Med 2020;383(18):1757-66.

5. T.C Sağlık Bakanlığı Halk sağlığı Müdürlüğü COVID-19 (SARS-CoV-2 infeksiyonu) Tedavi Rehberi Bilim Kurulu Çalışması 13 Nisan 2019. Accessed date: 17.02.2021. https:// www.teb.org.tr/versions_latest/1240/13nisansbrehberi
6. British Society of Thoraks Imagining. BSTI COVID-19 CT proforma. Accessed date: 01.04.2020. Avaliable from: https://www.bsti.org.uk/media/resources/files/BSTI_COVID_CT_Proforma_v.21-1.pdf.

7. Centers for Disease Prevention Investigative Criteria for Suspected Cases of SARS-CoV-2 Reinfection (ICR). Accessed date: 03.03.2021. Avaliable from: https://www.cdc.gov/ coronavirus/2019-ncov/php/reinfection.htm

8. World Health Organization (WHO). Clinical management of COVID-19 guidence. Interim guidance. WHO. 03.03.2021. Avaliable from: https://www.who.int/publications/i/item/ clinical-management-of-covid-19

9. Centers for Disease Control and Prevention (CDC). Clinical Care Guidance for Healthcare Professionals about Coronavirus (COVID-19). Accessed date: 03.03.2021 Avaliable from: https://www.cdc.gov/coronavirus/2019-ncov/hcp/ clinical-guidance-management-patients.html

10. Zhang J, Wang M, Zhao M, Guo S, Xu Y, Ye J, et al. The clinical characteristics and prognosis factors of mild-moderate patients with COVID-19 in a mobile cabin hospital: a retrospective, single-center study. Front Public Health 2020;8:264.

11. Wang X, Fang J, Zhu Y, Chen L, Ding F, Zhou R, et al. Clinical characteristics of non-critically ill patients with novel coronavirus infection (COVID-19) in a fangcang hospital. Clin Microbiol Infect 2020;26(8):1063-8.

12. Karakoç ZÇ, Pınarbaşı-Şimşek B, Asil R. First wave in COVID-19 pandemic: A single center experience. Klimik Derg 2020;33(3):223-9.

13. Güner R, Hasanoğlu I, Kayaaslan B, Aypak A, Kaya Kalem $A$, Eser F, et al. COVID-19 experience of the major pandemic response center in the capital: results of the pandemic's first month in Turkey. Turk J Med Sci 2020;50(8):1801-09.

14. Skipper CP, Pastick KA, Engen NW, Bangdiwala AS, Abassi $M$, Lofgren $S M$, et al. Hydroxychloroquine in nonhospitalized adults with early COVID-19: A randomized trial. Ann Intern Med 2020;173(8):623-31.

15. Cavalcanti $A B$, Zampieri $F G$, Rosa $R G$, Azevedo $L C P$, Veiga VC, Avezum A, et al. Hydroxychloroquine with or without azithromycin in mild-to-moderate COVID-19. N Engl I Med 2020;383(21):2041-52.

16. RECOVERY Collaborative Group, Horby P, Mafham M, Linsell L, Bell JL, Staplin N, et al. Effect of hydroxychloroquine in hospitalized patients with COVID-19. N Engl I Med 2020;383(21):2030-40.

17. Sümer ş, Ural O, Aktuğ-Demir N. Clinical and laboratory characteristics of COVID-19 cases followed in Selçuk University Faculty of Medicine. Klimik Derg 2020;33(2):122-7.

18. Gousseff M, Penot P, Gallay L, Batisse D, Benech N, Bouiller $K$, et al. Clinical recurrences of COVID-19 symptoms after recovery: Viral relapse, reinfection or inflammatory rebound? J Infect 2020;81(5):816-46.

19. Li $Q$, Zheng XS, Shen $X R$, Si HR, Wang X, Wang $Q$, et al. Prolonged shedding of severe acute respiratory syndrome coronavirus 2 in patients with COVID-19. Emerg Microbes Infect 2020;9(1):2571-7. 
20. To KK, Hung IF, Ip JD, Chu AW, Chan WM, Tam AR, et al. COVID-19 re-infection by a phylogenetically distinct SARS-coronavirus-2 strain confirmed by whole genome sequencing. Clin Infect Dis 2020: ciaa1275.

21. Tillett RL, Sevinsky JR, Hartley PD, Kerwin H, Crawford $N$, Gorzalski $A$, et al. Genomic evidence for reinfection with SARS-CoV-2: a case study. Lancet Infect Dis 2021;21(1):528.

22. Van Elslande J, Vermeersch P, Vandervoort K, Wawina-Bokalanga $T$, Vanmechelen $B$, Wollants $E$, et al. Symptomatic SARS-CoV-2 reinfection by a phylogenetically distinct strain. Clin Infect Dis 2020:ciaa1330.

23. Prado-Vivar B, Becerra-Wong M, Guadalupe JJ, Marquez S, Gutierrez B, Rojas-Silva P, et al. COVID-19 re-infection by a phylogenetically distinct SARS-CoV-2 variant, first confirmed event in South America. SSRN 2020, preprint.

24. Vasques Nonaka CK, Miranda Franco M, Gräf $T$, Almeida Mendes AV, Santana de Aguiar R, Giovanetti $M$, et al. Genomic evidence of a SARS-CoV-2 reinfection case with E484K spike mutation in Brazil. Reprints 2021.

25. Naveca F, da Costa C, Nascimento V, Souza V, Corado A, Nascimento F, et al. SARS-CoV-2 reinfection by the new Variant of Concern (VOC) P.1 in Amazonas, Brazil. Preprint 2021. Accessed date: 19.02.2021. Avaliable from:https:// virological.org/t/sars-cov-2-reinfection-by-the-new-variant-of-concern-voc-p-1-in-amazonas-brazil/596.

26. Resende PC, Bezerra JF, de Vasconcelos RHT, Arantes I, Appolinario L, Mendonça AC, et al. Spike E484K mutation in the first reinfection case confirmed in Brazil, 2020. Preprint. Published 2021. Accessed date: 19.02.2021. Avaliable from: https://virological.org/t/spike-e484k-mutation-in-the-first-sars-cov-2-reinfection-case-confirmed-in-brazil-2020/584.

27. Harrington $D$, Kele $B$, Pereira S, Couto-Parada X, Riddell $A$, Forbes $S$, et al. Confirmed Reinfection with SARS-CoV-2 Variant VOC-202012/01. Clin Infect Dis 2021:ciab014.

28. Zucman $N$, Uhel F, Descamps D, Roux D, Ricard JD. Severe reinfection with South African SARS-CoV-2 variant $501 Y$. V2: A case report. Clin Infect Dis 2021:ciab129.

29. Santhosh L, Block B, Kim SY, Raju S, Shah RJ, Thakur N, et al. How I Do It: Rapid Design \& Implementation of Post-COVID Clinics. Chest 2021:S0012-3692(21)00655-3.
30. Pan A, Liu L, Wang C, Guo H, Hao X, Wang Q et al. association of public health interventions with the epidemiology of the COVID-19 Outbreak in Wuhan, China. JAMA 2020;323(19):1915-23.

31. Kim G, Wang M, Pan H, H Davidson G, Roxby AC, Neukirch J, et al. A Health System Response to COVID-19 in LongTerm Care and Post-Acute Care: A Three-Phase Approach. J Am Geriatr Soc 2020;68(6):1155-61.

32. Gemelli Against COVID-19 Post-Acute Care Study Group. Post-COVID-19 global health strategies: the need for an interdisciplinary approach. Aging Clin Exp Res 2020;32(8):1613-20.

33. Huang C, Huang L, Wang Y, Li X, Ren L, Gu X et al.6-month consequences of COVID-19 in patients discharged from hospital: a cohort study. Lancet 2021;397(10270):22032.

34. Goërtz YMJ, Van Herck M, Delbressine JM, Vaes AW, Meys $R$, Machado FVC et al. Persistent symptoms 3 months after a SARS-CoV-2 infection: the post-COVID-19 syndrome? ERJ Open Res 2020;6(4):00542-2020.

35. Paderno A, Mattavelli D, Rampinelli V, Grammatica A, Raffetti E, Tomasoni M et al. Olfactory and gustatory outcomes in COVID-19: A prospective evaluation in nonhospitalized subjects. Otolaryngol Head Neck Surg 2020;163(6):11449.

36. Becker RC. COVID-19 and its sequelae: a platform for optimal patient care, discovery and training. J Thromb Thrombolysis 2021:1-8.

37. Bansal M. Cardiovascular disease and COVID-19. Diabetes Metab Syndr 2020;14(3):247-50.

\section{Yazıșma Adresi/Address for Correspondence}

\section{Dr. Arzu NAZLI}

Dokuz Eylül Üniversitesi Tıp Fakültesi,

İnfeksiyon Hastalıkları ve

Klinik Mikrobiyoloji Anabilim Dal,

İzmir-Türkiye

E-posta: arzunazli@hotmail.com 